\title{
Generation of Flood Map Using Infoworks for Sungai Johor
}

\author{
Noor Farahain Muhammad Amin ${ }^{1}$, Faridah Othman ${ }^{1, *}$ \\ ${ }^{1}$ Department of Civil Engineering \\ Faculty of Engineering, University of Malaya 50603, MALAYSIA.
}

Received 01 January 2018; accepted 15 April 2018, available online 07 May 2018

\begin{abstract}
Flood has become regular disaster in Malaysia which it is happens every year in different states especially during northeast monsoon. Johor State, the most southern part of Peninsular Malaysia experienced numerous flooding from 1926 to 2013. However, Sungai Johor catchment had the most devastating impact during December 2006 and January 2007 flood events. The objectives of this study are to perform river modeling and generate a flood map fpr Sungai Johor. The river modeling of Sungai Johor has been done using InfoWorks RS software. Necessary data were collected and transferred into the required modelling procedures. The results indicated that the model was able to simulate the flood depth to a reasonable agreement and generate the flood map. The generated flood map can serve as a beneficial planning and design tools for the local authority and community in minimizing the flood effects and damage as well as in preparing the evaluation plan.
\end{abstract}

Keywords: Flood map, InfoWorks RS, return period, river modeling, Sungai Johor

\section{Introduction}

Flooding is one of the natural hazards that frequently happens in Malaysia. Floods occur because of the rapid accumulation and release of runoff waters from upstream to downstream, which is caused by very heavy rainfall [1]. Practically, every year flood will occur in Malaysia with high amount of rainfall. This hazard becomes worse by the sophisticated development nowadays. Over 45 years, increasing in magnitude of flood and frequency triggered by human activities in many circumstances change flood behavior [2]. It has been estimated that about $29000 \mathrm{~km}^{2}$ or nine percent of total land area and more than 4.82 million people (22\%) is affected by flooding annually with damage cause by flood is estimated about RM915 million [3]. The combination of the extremes temperature in equatorial regions with the pressure gradients in these areas and the maritime exposure produces extreme weather conditions and the frequent occurrence of floods [4]. The river systems in Malaysia have 189 rivers flowing directly to the sea of which 85 are prone to frequent flooding [5].

Northeast Monsoon is from December to March cause of severe floods in several states located in Peninsular Malaysia during December 2006 and January 2007 floods [6]. These events had caused millions of lost and damages in four states namely Johor, Negeri Sembilan, Melaka and Pahang [7]. The period of the floods is on $19^{\text {th }}-31^{\text {st }}$ December 2006 for first wave and $12^{\text {th }}-17^{\text {th }}$ January 2007 for second wave. Sungai Johor catchment had the most devastating impact during December 2006 and January 2007 flood events. The floods brought large volume of runoff to the relatively large catchment of Sungai Johor. The average monthly precipitation is $200 \mathrm{~mm}$, but 2006 events gave an average of 50 years return period while 2007 storms gave an average of 100 years return period [5]. Areas that subjected to frequent flooding in Sungai Johor basin including Kota Tinggi town, Kampung Baru Sungai Telor, Kampung Tembioh, Kampung Batu 25, Kampung Sungai Berangan, Kampung Semangar Dalam, Kampung Semangar Luar, Kampung Jawa, Kampung Kelantan, Kampung Sungai Sembilang, Kampung Sri Jaya, Kampung Rantau Panjang, Kampung Panti, Kampung Sri Lalang, Kampung Sungai Tiram and Kampung Sungai Redan Laut [6].

In Malaysia, it is recently become a routine for the assessment of the risk of river basin at a range of scales from national assessment regarding the huge flooding event [8]. For water-related domains, good modeling practice has recently become a topical subject [9]. Modeling is an essential for the analysis, and especially for the prediction, of the dynamics of urban growth and how this, in turn, will impact back on the environment [10]. The modeling can generate the flood map for being an excellent tool to create awareness in mitigating hazard [11]. The main purpose of flood map is to gather in one 
map the hazard-related information for a study area to convey a composite picture of the natural hazards of varying magnitude, frequency, and area of effect [12]. A flood map may also be referred to as a composite, synthesized and overlay map [13].

In this paper, a river model was developed to generate the flood map of Sungai Johor for the management of the future flood in that basin. Even though many researchers have been working on the river model, very few researchers reported about the installation of the structure in the Sungai Johor model by using InfoWorks RS. The modeling with this structure can generate better flood hazard map and improve the river modeling.

\section{Study Area}

The southern region of Peninsular Malaysia is Johor state. Sungai Johor is $123 \mathrm{~km}$ long with a catchment of $2,636 \mathrm{~km}^{2}$ and flows in a roughly north-south direction, originating from Mount Gemuruh and then empties into the Strait of Johor. Its major tributaries are Sayong, Linggiu, Tiram and Lebam. The catchment is irregular in shape. The maximum length and width are $80-\mathrm{km}$ and $45-\mathrm{km}$ respectively. The basin is generally flat except on the northern and eastern region of the basin where land raises to an elevation approximately $500 \mathrm{~m}$ to $600 \mathrm{~m}$ in the east to a maximum of $1010 \mathrm{~m}$ to the north. The highland in the north is mainly jungle. In the south a major portion had been cleared and planted with palm oil and rubber. The highland areas have granite soil cover consisting of fine to coarse sand and clay. The alluvium consists of fine sand and clay. The catchment receives an average annual precipitation of $2,470-\mathrm{mm}$. The temperature in the basin ranges from $21^{\circ} \mathrm{C}$ to $32^{\circ} \mathrm{C}$.

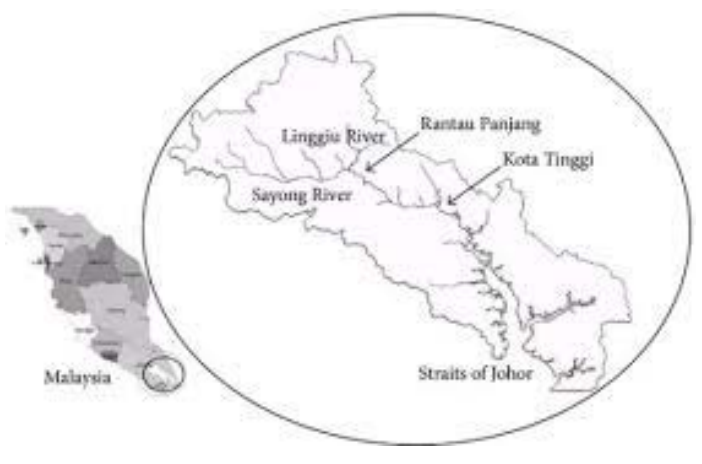

Fig. 1 The study area

\section{Methodology}

InfoWorks RS as a hydrodynamic modeling software includes full solution modeling of open channels, floodplains, embankments and hydraulic structures. Using both event based and conceptual hydrological methods, the rainfall-runoff simulation is also available using geographical plan views, sectional view, long sections, spreadsheet and time varying graphical data in full interactive views of data. The underlying data can be accessed from any graphical or geographical view. Full flood mapping capability is provided based on a sophisticated flood-interpolation model overlaid onto an imported ground model [14].

The data required in setting up this model includes the river spatial and geometrical data, hydraulics and hydrological data. In constructing the Sungai Johor model used in this study, the digital geometric data in Shape format file was imported into InfoWorks RS as a background. The spatial locations of the river and their properties were obtained from the digital map and DEM using GIS techniques.

The cross-section profiles of Sungai Johor basin were obtained from the Department of Irrigation and Drainage (DID). There are 143 river cross-section profiles, and the chainages interval used in this study is a thousand meters. However, in some locations that are more prone to flooding and more developed area, smaller intervals of 250 meters were used. This is done so that the water level and flood depth can be calculated more accurately

The digital map is shown in Fig. 2. The river system is divided into 7 sub-catchments in this study namely Rantau Panjang, Lebak, Semangar, Telor, Pelepah, Kota Tinggi 1 and 2. Flow-time boundary was applied on Rantau Panjang as the upstream inflow hydrographs. A stage-time boundary was used as downstream boundary in Seluyut. Internal boundaries for the sub catchments were modeled as rainfall boundary. Figure 3 shows the layout of the model and the location of the cross-sections along Sungai Johor.

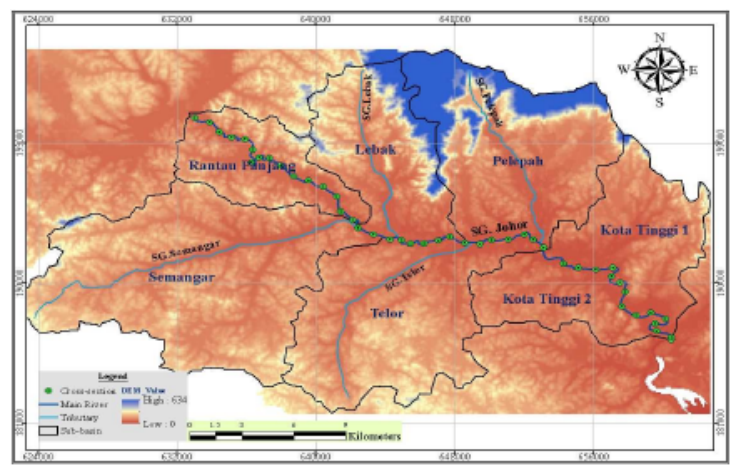

Fig. 2 The map of Sungai Johor basin

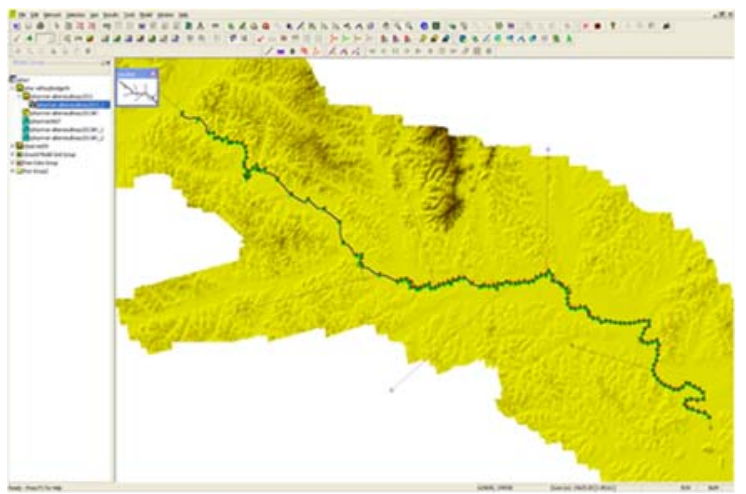

Fig. 3 Layout of the model 


\section{Result and Discussion}

The flooding area in Sungai Johor spreads from the upstream of Rantau Panjang until the downstream of Kota Tinggi. The high water level along Sungai Johor can be shown in longitudinal section view from the upstream Rantau Panjang until the downstream at Sungai Seluyut and the view is illustrated in Figure 4 . This figure gives the overview of the water level for the complete section of the river. At any section that the water level is higher than the bank level, flood will occur.

The model was calibrated against the observed water level and discharge data at the relevant gauging stations and has shown a reasonable agreement. The simulated flood depth has also been compared to the observed flood depth and has shown a good agreement as given in Table 1 below.

Table 1: Comparison of simulated and actual flood depth

\begin{tabular}{llclr}
\hline Location & \multicolumn{2}{c}{ Simulated } & \multicolumn{2}{c}{ Observed Flood } \\
& \multicolumn{2}{c}{ Flood depth } & \multicolumn{2}{c}{ Depth } \\
& 2006 & 2007 & 2006 & 2007 \\
\hline Rantau Panjang & 1.9 & 3.2 & 2.1 & 3.13 \\
Kota Tinggi & 2.19 & 2.9 & 2.3 & 2.75 \\
\hline
\end{tabular}

The flood hazard map has been produced to give more visualization to the area where the inundation area is. Figure 5 shows the flood hazard map during the flooding events in 2006. It can be seen that the water overflows to the extended flood area.

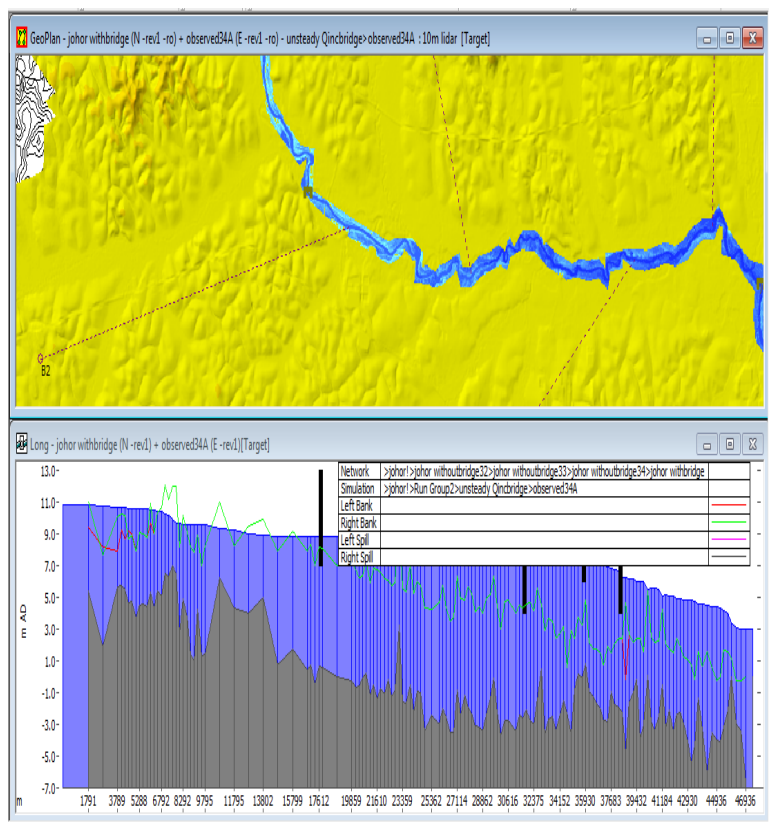

Fig. 4. Long section view of Sungai Johor

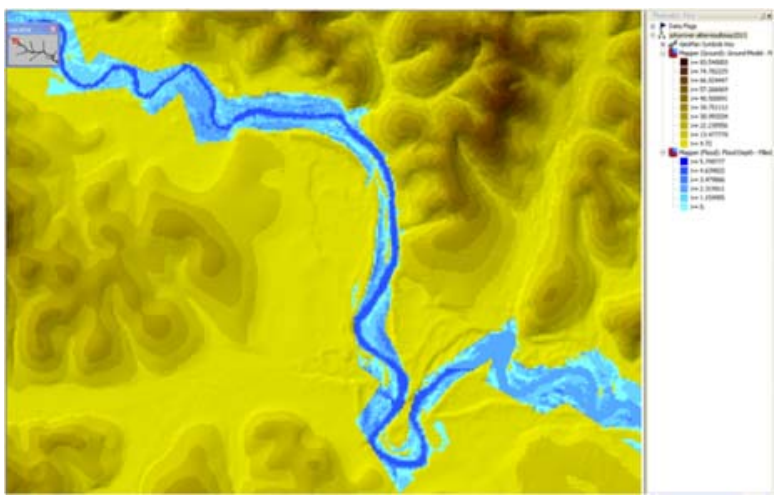

Fig. 5 Johor River Flood Map during flooding in 2006.

\section{Conclusion}

A river model and flood map has been generated using the Infoworks RS software. The model has shown a reasonable agreement between the observed and simulated data. River modeling can be very useful solution as assessment and prediction can always be done with sufficient data. The generated flood map can help the administrative bodies in the area by giving them the information on which areas are affected by flood. Further analysis can be done using difference scenarios and various return periods as well as future land use planning to minimize flooding risks. It can serve as a beneficial planning and design tools for the local authority and community in minimizing the flood effects and damage as well as in preparing the evaluation plan.

Moreover, this model can be further improved by using 2-D hydraulic model to incorporate more valuable information for management and planning purposes.

\section{Acknowledgements}

The authors would like to acknowledge the Department of Irrigation and Drainage Malaysia and The Regional Humid Tropics and Water Resources Centre for Southeast and The Pacific (HTC) for their support and co-operation given in doing this study. The authors would like to thank University Malaya Research Grant (RP017C-15SUS) and Trans-disciplinary Grant Scheme Minister of Higher Education (TR001B-2015) for financial support. We would also like to express our sincere gratitude to the to the Water Research Center of UM and everybody involved for their assistance and guidance throughout the study period.

\section{References}

[1] Ouma, Yashon O., \& Tateishi, Ryutaro. (2014). Urban Flood Vulnerability and Risk Mapping Using Integrated Multi-Parametric AHP and GIS: Methodological Overview and Case Study Assessment. Water, 6(6), 1515-1545. 
[2] Toriman, Mohd Ekhwan, Hassan, A. Jalil, Gazim, M. Barzani, Mokhtar, Mazlin, Mastura, S.A. Sharifah, Jaafar, Osman, Aziz, \& Nor Azlina Abdul. (2009). Integration of 1-d hydrodynamic model and GIS approach in flood management study in Malaysia. Research Journal of Earth Sciences, 1(1), 22-27.

[3] Hassan, Abd Jalil, \& Abdullah, B. (2002). Penggunaan teknologi terkini ke arah pengurusan banjir yang bersepadu. Persidangan Pengurus Kanan JPS, 9-11.

[4] Shafie, Atikah. (2009). A Case Study on Floods of 2006 and 2007 in Johor, Malaysia. Colorado State University.

[5] DID. (2009). Design manual Volume 1: Department of Irrigation and Drainage, Malaysia.

[6] Bhd, K\&L Jurutera Perunding Sdn. (2009). Kajian Pelan Induk Tebatan Banjir bagi Lembangan Sungai Johor, Final Report (Vol. 3). Malaysia: Jabatan Pengairan dan Saliran.

[7] Othman, F., Amin, M.F, Lau, M.F., and Alaa Eldin M.E.,(2013). Utilizing GIS and Infoworks RS in modelling the flooding events for a tropical river basin. Paper presented at the Applied Mechanics and Materials.

[8] Dawson, R., Speight, L., Hall, J., Djordjevic, S., Savic, D., \& Leandro, J. (2008). Attribution of flood risk in urban areas. Journal of Hydroinformatics, 10(4), 275-288.

[9] Vidal, J., Moisan, Sabine, Faure, J., \& Dartus, Denis. (2005). Towards a reasoned 1D river model calibration. Journal of Hydroinformatics, 7, 91-104.

[10] Wicks, J.M., Hu, C., Scott, M., Chen, L., \& Cheng, X. (2013). A broad scale model for flood simulation in the Taihu Basin, China. Journal of Flood Risk Management, 6(1), 33-41.

[11] Islam, A. (2010). Improving flood forecasting in Bangladesh using an artificial neural network. Journal of Hydroinformatics, 12(3), 351-364.

[12] Kalyanapu, A.J., Judi, D.R., McPherson, T.N., \& Burian, S.J. (2012). Monte Carlo - based flood modelling framework for estimating probability weighted flood risk. Journal of Flood Risk Management,5(1),37-48.

[13] Ali, Paridah Anun \& Anuar. (2007). Preparation of Flood Hazard Maps for Kota Tinggi Town. Malaysia: Department of Irrigation and Drainage, Malaysia.

[14] Salarpour, Mohsen, Rahman, Norhan Abd, \& Yusop, Zulkifli. (2011). Simulation of flood extent mapping by InfoWorks RS-case study for tropical catchment. J. Software Eng, 5, 127-135. 